\title{
Economic policy and confidence of economic agents - a causal relationship?
}

\section{Silvo Dajčman ${ }^{1}$}

\begin{abstract}
The purpose of this paper is to study whether innovations in monetary and fiscal policy are a leading indicator of future business and consumer confidence and reverse applying the panel Granger causality analysis to two periods in the history of the euro area: before and after the start of the Great Recession. The results show that Granger causality interaction between the confidence of economic agents and the stance of monetary policy (measured by the shadow rate) is stronger than between the former and the fiscal policy instruments. The European Central Bank (ECB) shadow rate innovations Granger caused business and consumer confidence in both periods, but also indicators of confidence Granger caused the shadow rate. No such feedback could be established between two fiscal policy instruments (government expenditure and revenue growth) and the indicators of confidence. Government spending and revenues Granger caused business confidence in the first subperiod, but not in the second subperiod when the causality reversed. The government revenues Granger caused consumer confidence in the first subperiod, while government expenditures in the second subperiod. Consumer confidence Granger caused government spending in the first subperiod.
\end{abstract}

Keywords: fiscal policy, monetary policy, consumer confidence, business confidence, panel Granger causality

JEL classification: E52, E62, E63, H31, H32

Received: 10 April 2020 / Accepted: 24 September 2020 / Sent for Publication: 7 December 2020

\section{Introduction}

According to Eurostat (2020d) data, in March 2009 consumer and business confidence in the euro area fell to its lowest record, coinciding with the Great Recession. While business confidence recovered, consumer confidence remained subdued until the end of 2012, when both measures of expectations (or beliefs) about the economic outlook deteriorated rapidly again amid the eurozone crisis. A growing body of literature has recently identified economic agents' confidence as an independent generator of macroeconomic fluctuations (Leduc and Sill, 2013; Beaudry and Portier, 2014). While business and consumer confidence can be influenced by several factors, including major economic and political shocks, natural disasters, and health threats like the recent coronavirus outbreak, the same can be argued with respect to fiscal and monetary policy. Policy makers thus may have the tools to steer the confidence ${ }^{2}$, as studied recently for monetary policy

\footnotetext{
${ }^{1}$ University of Maribor, Faculty of Economics and Business, Razlagova 14, 2000 Maribor, Slovenia, e-mail: silvo.dajcman@um.si

${ }^{2}$ See Bachmann and Sims (2012) and the media quotations therein.

C 2020 by the authors; licensee Review of Economic Perspectives / Národohospodářský obzor, Masaryk University, Faculty of Economics and Administration, Brno, Czech Republic. This article is an open access article distributed under the terms and conditions of the Creative Commons Attribution 3.0 license, Attribution - Non Commercial - No Derivatives.
} 
(Debes et al., 2014; Claus and Nguyen, 2019; Lewis et al., 2019; Kirchner, 2020) and fiscal policy (Konstantinou and Tagkalakis, 2011; Bachmann and Sims, 2012; Alesina et al., 2015; Beetsma et al., 2015). Given that consumer confidence and business confidence are part of the information set of central banks' policy design and are likely to be considered by fiscal policy makers, swings in confidence may influence monetary and fiscal policy decisions. To the best of our knowledge, the reverse causality between the confidence of economic agents and economic (monetary and fiscal) policy has not yet been researched. This study aims to fill this gap in the literature.

The results may have important policy implications. Following the literature that examines how confidence affects economic activity (e.g., Matsusaka and Sbordone, 1995; Chauvet and Guo, 2003; Leduc and Sill, 2013), a finding that economic policy Granger causes confidence of economic agents implies that economic policy can affect economic dynamics (also) by this channel (see Bachmann and Sims, 2012). If reverse causality is established, this may imply that the confidence of economic agents affects the design of the economic policy.

The existing studies (Konstantinou and Tagkalakis, 2011; Bachmann and Sims, 2012; Alesina et al., 2015; Beetsma et al., 2015; Claus and Nguyen, 2019; Kirchner, 2020) examine the effect of economic policy on economic agents' confidence for monetary or fiscal policy alone. Strong empirical evidence (e.g., Rossi and Zubairy, 2011; Molteni and Pappa, 20173), however, suggests that due to interdependencies between monetary and fiscal policy, they should be modeled in a unified empirical framework.

This study fits a panel multivariate Vector Autoregressive (VAR) model for the euro area and applies Granger causality analysis to study whether innovations in monetary (shadow rate of ECB) and fiscal policy instruments (government spending and revenue of euro area countries) are predictive (or a leading indicator) of future business and consumer confidence and the reverse (reverse Granger causality), once fundamentals (gross domestic product (GDP) and price level growth) are accounted for.

The Great Recession triggered a major response of monetary and fiscal policy around the world, and as the economic policy makers have adopted some unconventional measures, the relationship between economic policy and confidence of economic agents may have changed structurally. The relationship between the variables is therefore studied for the period before the Great Recession and the period afterwards.

\section{Literature review}

The theoretical and empirical literature on the relationship between economic policy and the confidence of economic agents is thin. The theoretical explanation for the role of monetary and fiscal policy in the formation of confidence of economic agents is provided by models of De Grauwe (2011), Bofinger et al. (2013), Debes et al. (2014), and Guimaraes et al. (2016), while the effect of shocks in confidence on the design of optimal economic policy has recently been investigated by the "expectations-driven liquidity trap" models of Mertens and Ravn (2014), Schmidt (2016), and Nakata and Schmidt (2019).

\footnotetext{
${ }^{3}$ See also other references in Molteni and Pappa (2017).
} 
De Grauwe (2011) assumes that economic agents have a limited capability to process information. The agents therefore adopt simple heuristic rules that lead to heterogenous beliefs about the economy's prospects. In this setting, economic shocks lead to aggregate swings of pessimism and optimism, which in turn can generate economic fluctuations (animal spirits). De Grauwe (2011) shows that monetary policy that stabilizes economic fluctuations can also stabilize the volatility of beliefs. Bofinger et al. (2013) adopt similar behavioral assumptions and study connection between monetary policy and house prices. They show that expansionary monetary policy increases the share of agents following optimistic house price expectations and this optimism feeds through to the macroeconomy. Debes et al. (2014) find that monetary policy causes "contagion" of expectations, which spurs aggregate shifts in consumer confidence. Although the above studies focus on the central bank's ability to affect confidence, their results imply that confidence can affect monetary policy too (e.g., by following the Taylor rule). While the studies mentioned above focus on monetary policy, Guimaraes et al. (2016) focus on fiscal policy. In a theoretical model, they show that government spending increases the economic agents' belief that investment activity in the economy will increase. This stimulates business investment and improves the prospects of economic activity in general.

Mertens and Ravn (2014), Schmidt (2016), and Nakata and Schmidt (2019) develop models in the New Keynesian setting that try to explain how the shocks in confidence of economic agents affect the design of optimal economic policy (mix). The authors note that a negative shock to fundamentals or to confidence of economic agents can cause a liquidity trap and the optimal design of monetary and fiscal policy is dependent on whether the liquidity trap is caused by the former or the later. The same set or mix of economic policy can result in very different macroeconomic outcomes depending on the cause of liquidity trap (ibidem).

The empirical literature separately examines the effect of monetary policy and fiscal policy on the confidence. The effect of monetary policy on confidence has been studied by Debes et al. (2014), Claus and Nguyen (2019), Lewis et al. (2019), and Kirchner (2020). Debes et al. (2014) fit a four-variable VAR for the United States (US) to study the US consumer confidence response (measured by the Michigan Survey of Consumers) to a restrictive federal funds rate shock. The remaining variables in the model are GDP growth and inflation. They find that confidence drops significantly in response to a contractionary monetary policy shock. Claus and Nguyen (2019) study the short-term and long-term response of consumer confidence (measured by the Consumer Attitudes, Sentiments, and Expectations Survey) to monetary policy shocks in Australia, by fitting a latent factor and non-linear autoregressive distributed lag (NARDL) model. They find that consumer confidence generally drops after monetary policy tightening and increases after monetary policy easing in both the short and long term. Lewis et al. (2019) use US Daily Survey Poll of Gallup data to study how Federal Reserve announcements affect consumer confidence. By local projections method, they find that announcements of policy rate hikes have an immediate negative effect, whereas announcements about nonconventional monetary policy measures (forward guidance and large-scale asset purchase programs) do not have a significant impact on confidence. Kirchner (2020) fits a regression model for Australia, controlling for different economic and financial variables, and finds that increases in monetary policy rates depress consumer confidence (measured by the Westpac-Melbourne Institute Index of Consumer Sentiment). 
The effect of fiscal policy on confidence is studied by Konstantinou and Tagkalakis (2011), Bachmann and Sims (2012), Alesina et al. (2015), and Beetsma et al. (2015). Konstatinou and Tagkalakis (2011) study nine Organization for Economic Cooperation and Development (OECD) countries to investigate how different government spending and revenue variables affect consumer and business confidence. Applying a panel regression modeling framework, they find that higher non-wage government spending and direct tax reductions increase consumer and business confidence, while other components have an insignificant effect. Bachmann and Sims (2012) study for the US the effect of government spending shocks using the Michigan Survey of Consumer Confidence. A three-variable VAR, including consumer confidence, GDP, and government spending, is fitted. Their results show no significant consumer confidence response to government spending shocks. Alesina et al. (2015), on a sample of 16 OECD countries, study the effect of fiscal consolidation on business and consumer confidence, applying a six-variable panel model. They separate expenditure-based and tax-based consolidation plans, the former based primarily on spending cuts and the latter on tax cuts, and find that tax-based consolidation has a larger effect than expenditure-based consolidation on both business confidence and consumer confidence. Beetsma et al. (2015) also investigate the effects of fiscal consolidation announcements on confidence. They fit a panel model on a sample of 17 OECD countries to show that consolidations reduce consumer and business confidence, the former generally more than the latter. They find that revenue-based consolidation effects are stronger than expenditure-based consolidation effects. The effect on confidence seems to differ during different phases of the business cycle: While consolidations reduce consumer confidence in booms, they boost it in busts.

To the best of our knowledge, the reverse causality between the confidence of economic agents and economic policy has not yet been empirically researched.

\section{Methodology}

Granger causality between economic policy and business and consumer confidence is estimated in a multivariate panel VAR framework for two reasons. First, the time series for variables in our model is relatively short for some countries. A switch from time series to panel data results in more reliable estimation and inference results (Hsiao, 1986; Canova and Cicarelli, 2013). Second, as Hsiao (1982), Eichler (2013), and Song and Taamouti (2018) point out, causality between two variables in a bivariate setting can be spurious or indirect if relevant variables that can affect the cause-effect relationship between two variables are omitted. From the theoretical and empirical literature listed above, empirical modelling of interactions between the confidence of economic agents and economic policy thus demands that important macroeconomic variables (fundamentals) $^{4}$ are controlled for. Following Rossi and Zubairy (2011) and Molteni and

\footnotetext{
${ }^{4}$ In the literature, changes in confidence (changes in expectations (beliefs) about the future economic conditions), unrelated to fundamentals are often denoted as "animal spirits," or "pure sentiment" (Bachman and Sims, 2012), but we will refer to it simply as confidence, following some parts of the literature (e.g., Konstantinou and Tagkalis, 2011). Recent empirical research has also developed more sophisticated methods to discern this component of confidence from the "news"
} 
Pappa (2017), interactions between confidence and monetary and fiscal policy measures are studied simultaneously.

Granger causality testing proceeds in two steps. In the first step, the dynamic relationship between relevant variables is modeled by the following panel VAR model (see Abrigo and Love, 2016):

$$
X_{i t}=\eta_{i}+B_{1} X_{i t-1}+B_{2} X_{i t-2}+\cdots+B_{q} X_{i t-q}+u_{i t}
$$

where $i=1, \ldots, N$ is a set of countries, $t=1, \ldots, T$ is time, $X_{i t}$ is an $M \times 1$ vector of endogenous stationary variables, including the growth of real GDP $\left(r g d p_{i t}\right)$ and the growth of real government expenditure and revenue $\left(r g_{i t}\right.$ and $r t_{i t}$, respectively), expressing a stance of fiscal policy on the expenditure and revenue side, inflation $\left(\pi_{i t}\right)$, changes (i.e., first difference) in monetary policy (shadow) rate $\left(\right.$ drate $\left._{t}\right)$ representing monetary policy stance, and an indicator of confidence of economic agents, that is, business $\left(B C_{i t}\right)$ and consumer $\left(C C_{i t}\right)$ confidence, one at a time, respectively. $B_{1}, B_{2}, \ldots, B_{q}$ is an $M \times M$ matrix of parameters, $\eta_{i}$ is an $\mathrm{N} \times 1$ vector of country (fixed) effects that captures specific country heterogeneities that are constant over time $e^{5}, q$ is the autoregressive lag of the panel VAR model, and $u_{i t}$ is an $M \times 1$ vector of idiosyncratic errors. Following Abrigo and Love (2016), the efficient parameter estimates are obtained by the generalized method of moments (GMM) estimator once the variables in (1) have been forward orthogonal deviation transformed, as first proposed by Arellano and Bover (1995). As Abrigo and Love (2016) suggest, the optimal lag selection ( $q$ ) is determined by Andrews and Lu's (2001) method of moments information criteria - we opted for the Akaike information criteria - conditioned on the Hansen (1982) J test. Robust standard errors of parameter estimates are computed. All computations are in Stata, using Abrigo and Love's (2016) routines pvar and pvarsoc.

The second step consists of testing the Granger causality, based on the results of model equation (1). Suppose that we are interested in whether variable $j$ does not Granger cause variable $m$, implying that variable $j$ has no power to explain (is not predictive of) variation in variable $m$ (see, e.g., Greene, 2002, 592) or no forecasting power (e.g., Hamilton, 1994, 303 ), conditional on the past realization of other variables in (1) (see Eichler, 2013) ${ }^{6}$. Let us define $B_{s}(m, j)$, where $s=1, \ldots, q, 1 \leq m \leq M$, and $1 \leq j \leq M$, an estimated parameter of model equation (1). The null hypothesis, that variable $j$ does not Granger cause variable $m$, is (see, e.g., Eichler, 2013):

$$
H_{0}: B_{s}(m, j)=0 \forall s,
$$

against the alternative (of variable $j$ Granger causing variable $m$ ):

$$
H_{1}: B_{s}(m, j) \neq 0 \forall s .
$$

component (i.e. innovations in the confidence indicator that are associated with the fundamentals) (see, e.g., Beaudry and Portier, 2014; Barsky and Sims, 2012).

${ }^{5}$ This specification does not allow for country-specific parameter estimates, which thus can be interpreted as representing an average euro area response.

${ }^{6}$ Following a suggestion of an anonymous referee, the term "leading indicator" is also used in the paper as a synonym of the terms. 
The Wald test is applied to test the hypothesis. There is a feedback mechanism (reverse causality) if variable $j$ Granger causes variable $m$ and at the same time variable $m$ Granger causes variable $j$. The test is performed by using Abrigo and Love's (2016) pvargranger Stata routine.

\section{Data}

Model equation (1) is estimated on quarterly data for 14 euro area countries for which seasonally adjusted data on government expenditure and revenue are available. The panel is unbalanced, ranging from $1999 \mathrm{q} 1$, the inception of common monetary policy in the euro area, until 2019q3, the last available macroeconomic data. The panel is unbalanced because the data availability differs for the sampled countries. The validity of the GMM estimator is conditional on the stationarity of the variables entering model equation (1) (see Bond, 2002, and Abrigo and Love, 2016); therefore, the variables are transformed to achieve stationarity. A description of the data, necessary transformations to achieve stationary, and data sources are presented in Table 1.

Table 1. Description of variables, sample period and data sources

\begin{tabular}{|l|l|}
\hline \multicolumn{1}{|c|}{ Variable } & \multicolumn{1}{c|}{ Description } \\
\hline$r g d p_{i t}$ & $\begin{array}{l}\text { Quarterly real (chain-linked) growth of gross domestic product }\left(G D P_{i t}\right), \\
\text { computed from seasonally and working day adjusted data (for Slovakia only } \\
\text { seasonally adjusted) obtained from Eurostat (2020a). Growth is computed as } \\
\text { the first difference of the logarithm. }\end{array}$ \\
\hline$r g_{i t}$ & $\begin{array}{l}\text { The quarterly real growth of total central government expenditures, seasonally } \\
\text { and working day adjusted. Expenditure data from Eurostat (2020b) were } \\
\text { deflated by the Harmonized Index of Consumer Prices (HICP). Growth is } \\
\text { calculated as the first difference of the logarithm of the time series. }\end{array}$ \\
\hline$r t_{i t}$ & $\begin{array}{l}\text { The quarterly real growth of total central government revenue, seasonally and } \\
\text { working day adjusted. Expenditure data from Eurostat (2020b) were deflated } \\
\text { by HICP. Growth is calculated as the first difference of the logarithm of the } \\
\text { time series. }\end{array}$ \\
\hline$\pi_{i t}$ & $\begin{array}{l}\text { Quarterly inflation, seasonally adjusted. Eurostat (2020c) data on the HICP } \\
\text { were seasonally adjusted by JDemetra (see Grundowska, 2015), and then the } \\
\text { first difference of the logarithm was computed. }\end{array}$ \\
\hline$d r a t e_{t}$ & $\begin{array}{l}\text { The first difference of the average quarterly shadow rate of the European } \\
\text { Central Bank, computed from daily estimates by Krippner (2015) } \\
\text { the stance of monetary policy in the euro area. The data source, policy rates in } \\
\text { level, is the Reserve Bank of New Zealand (2020). }\end{array}$ \\
\hline$B C_{i t}$ & $\begin{array}{l}\text { Business confidence, represented by industrial confidence, average quarterly } \\
\text { level, computed from monthly data. The data are seasonally adjusted (see } \\
\text { European Commission (2019) on details of how the industrial confidence is } \\
\text { estimated). Data source is Eurostat (2020d). The series is seasonally adjusted. }\end{array}$ \\
\hline$C C_{i t}$ & $\begin{array}{l}\text { Consumer confidence, average quarterly level, computed from monthly data. } \\
\text { The data are seasonally adjusted (see European Commission (2019) for details } \\
\text { of how the consumer confidence is estimated). The data source is Eurostat } \\
\text { (2020d). The series is seasonally adjusted. }\end{array}$ \\
\hline
\end{tabular}

\footnotetext{
${ }^{7}$ See Krippner (2015) for how the shadow rate can be used to capture the monetary policy stance in the era of zero lower bound.
} 
Countries included in the sample and period covered: Belgium (1999q1-2019q3), Germany (2002q1-2019q3), Estonia (2011q1-2019q3), France (1999q1-2019q3), Latvia (2014q12019q3), Lithuania (2015q1-2019q3), Luxembourg (2002q1-2019q3), Malta (2008q12019q3), Netherlands (1999q1-2019q3), Austria (2001q1-2019q3), Portugal (1999q1-2019q3), Slovenia (2007q1-2019q3), Slovakia (2009q1-2019q3), Finland (1999q1-2019q3).

ADF time series and a Fisher-type panel unit root test (Choi, 2001) were applied to test for stationarity of presented data. The results, not presented but obtainable upon request from the author, indicate that variables entering model equation (1) are stationary, some in untransformed form $\left(B C_{t}, C C_{t}\right)$, while others are after first differencing $\left(r g d p_{t}, r g_{i t}\right.$, $r t_{i t}, \pi_{i t}$, drate $\left._{t}\right)$.

\section{Results and discussion}

The results of Granger causality testing are presented next. The results of the tests for the panel VAR model equation (1) with business confidence $\left(B C_{i t}\right)$ for the period prior to the Great Recession (1999q1-2008q3) are presented in Table 2, while Table 3 presents the results for the second period (2008q4-2019q3). In our discussion of results, we focus on Granger causality testing between the economic policies and consumer confidence (shaded in grey), but Tables 2 and 3 present the results of Granger causality testing for all pairs of endogenous variables.

Table 2: Granger causality between fiscal/monetary policy and business confidence in period 1999q1-2008q3

\begin{tabular}{|c|c|c|c|c|c|}
\hline $\begin{array}{c}\text { Variable } \\
\mathrm{s} \\
\text { Granger } \\
\text { causing } \\
B C_{i t}\end{array}$ & $\begin{array}{c}\text { Variables } \\
\text { Granger } \\
\text { causing } \\
r g_{i t}\end{array}$ & $\begin{array}{c}\text { Variables } \\
\text { Granger } \\
\text { causing } \\
r t_{i t}\end{array}$ & $\begin{array}{c}\text { Variables } \\
\text { Granger } \\
\text { causing } \\
\text { drate }_{t}\end{array}$ & $\begin{array}{c}\text { Variables } \\
\text { Granger } \\
\text { causing } \\
r g d p_{i t}\end{array}$ & $\begin{array}{c}\text { Variables } \\
\text { Granger } \\
\text { causing } \\
\pi_{i t}\end{array}$ \\
\hline $\begin{array}{l}r g_{i t} \\
\stackrel{* * *}{\rightarrow} B C_{i t} \\
\end{array}$ & $B C_{i t} \stackrel{N o}{\rightarrow} r g_{i t}$ & $B C_{i t} \stackrel{N o}{\rightarrow} r t_{i t}$ & $B C_{i t} \stackrel{* * *}{\rightarrow}$ drate $_{i t}$ & $B C_{i t} \stackrel{* * *}{\rightarrow} r g d p_{i t}$ & $B C_{i t} \stackrel{N o}{\rightarrow} \pi_{i t}$ \\
\hline $\begin{array}{l}r t_{i t} \\
\text { No } \\
\rightarrow B C_{i t}\end{array}$ & $r t_{i t} \stackrel{\text { No }}{\rightarrow} r g_{i t}$ & $r g_{i t} \stackrel{* * *}{\rightarrow} r t_{i t}$ & $r g_{i t} \stackrel{* *}{\rightarrow}$ drate $_{i t}$ & $\mathrm{rg}_{i t} \stackrel{\text { No }}{\rightarrow} \mathrm{rgdp} p_{i t}$ & $r g_{i t} \stackrel{* *}{\rightarrow} \pi_{i t}$ \\
\hline $\begin{array}{l}\text { drate }_{i t} \\
\stackrel{* *}{\rightarrow} B C_{i t}\end{array}$ & $\begin{array}{l}\text { drate }_{i t} \\
\text { No } \\
\rightarrow r_{i t}\end{array}$ & $\begin{array}{l}\text { drate }_{i t} \\
\stackrel{* * *}{\rightarrow} r t_{i t}\end{array}$ & $r t_{i t} \stackrel{\text { No }}{\rightarrow}$ drate $_{i t}$ & $r t_{i t} \stackrel{\text { No }}{\rightarrow} r g d p_{i t}$ & $r t_{i t} \stackrel{* * *}{\rightarrow} \pi_{i t}$ \\
\hline $\begin{array}{l}r g d p_{i t} \\
\stackrel{* * *}{\rightarrow} B C_{i t}\end{array}$ & $\begin{array}{l}r g d p_{i t} \\
\stackrel{N o}{\rightarrow} r g_{i t}\end{array}$ & $\begin{array}{l}r \underset{* g}{r g} d p_{i t} \\
\stackrel{*}{\rightarrow} r t_{i t}\end{array}$ & $\begin{array}{l}r g d p_{i t} \\
\stackrel{* * *}{\rightarrow} d_{\text {rate }}\end{array}$ & $\begin{array}{l}\text { drate }_{i t} \\
\stackrel{* * *}{\rightarrow} r g d p_{i t}\end{array}$ & $\begin{array}{l}\underset{* * *}{\rightarrow} \pi_{i t} \\
\stackrel{*}{\rightarrow} \pi_{i t}\end{array}$ \\
\hline$\stackrel{\pi_{i t}}{\stackrel{* * *}{\rightarrow}} B C_{i t}$ & $\pi_{i t} \stackrel{* * *}{\rightarrow} r g_{i t}$ & $\pi_{i t} \stackrel{* * *}{\rightarrow} r t_{i t}$ & $\pi_{i t} \stackrel{* * *}{\rightarrow}$ drate $_{i t}$ & $\pi_{i t} \stackrel{* * *}{\rightarrow} r g d p_{i t}$ & 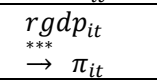 \\
\hline
\end{tabular}

Notes: The table reports the results of the Granger causality tests, based on equations (1)-(3). The number of lags of instrument variables is set to 4 and the number of lag order of panel VAR, $q$, is 2, determined as specified above. The direction of the arrow indicates the direction of Granger causality (the first variable causing the second), while the significance level of the rejection of the null hypothesis of no Granger causality is indicated by the arrow: No denotes that the null hypothesis (of no Granger causality) cannot be rejected, while */**/*** denote that the hypothesis of no Granger causality can be rejected at the 10\%, 5\%, and 1\% significance level, respectively. 
Prior to the start of the Great Recession, all variables but the growth in government revenue $r t_{i t}$ were a leading indicator for (i.e. Granger caused) business confidence $\left(B C_{i t}\right)$ in the euro area (on average). Growth in government expenditure $\left(r g_{i t}\right)$ is statistically significant at $1 \%$, while changes in the ECB shadow rate $\left(\right.$ drate $\left._{i t}\right)$ are at the $5 \%$ level. Business confidence was a leading indicator for the ECB shadow rate, but not the growth in fiscal variables (expenditure and revenue). The feedback (reverse causality) between business confidence and changes in monetary policy rate implies that monetary policy influenced the formation of business confidence, but also business confidence affected the ECB's policy making. Indeed, the ECB, within the two-tier monetary policy strategy, has observed a wide range of monetary and economic indicators (our results demonstrate that all variables but $r t_{i t}$ were a leading indicator for $d r a t e_{i t}$ ), and business confidence likely is an important part of its information set. No such strong relationship (no reverse Granger causality) is observed between fiscal policy making and business confidence. Note also that $B C_{i t}$ Granger caused the real growth of GDP $\left(r g d p_{i t}\right)$, a result that is consistent with Leduc and Sill (2013), and Beaudry and Portier (2014), among others, who identify an important role of economic agent confidence in business cycle fluctuations.

During the second subperiod (2008q4-2019q3; Table 3), a strong interdependence (reverse Granger causality) between changes in the ECB's shadow rate and business confidence can still be observed. With regards to fiscal policy variables, changes in fiscal policy instruments had no Granger-causal effect on business confidence in this period. While insignificant in the first subperiod, business confidence could help to predict (was leading indicator for) the growth of government spending in this subperiod. In line with the established result from the first subperiod, business confidence also was a leading indicator for the real growth of GDP in this subperiod.

Table 3: Granger causality between fiscal/monetary policy and business confidence in period 2008q4-2019q3

\begin{tabular}{|c|c|c|c|c|c|}
\hline $\begin{array}{c}\text { Variable } \\
\mathrm{s} \\
\text { Granger } \\
\text { causing } \\
B C_{i t}\end{array}$ & $\begin{array}{c}\text { Variables } \\
\text { Granger } \\
\text { causing } \\
r g_{i t}\end{array}$ & $\begin{array}{c}\text { Variables } \\
\text { Granger } \\
\text { causing } \\
r t_{i t}\end{array}$ & $\begin{array}{c}\text { Variables } \\
\text { Granger } \\
\text { causing } \\
\text { drate }_{t}\end{array}$ & $\begin{array}{c}\text { Variables } \\
\text { Granger } \\
\text { causing } \\
\text { rgdp } p_{i t}\end{array}$ & $\begin{array}{c}\text { Variables } \\
\text { Granger } \\
\text { causing } \\
\pi_{i t}\end{array}$ \\
\hline $\begin{array}{l}r g_{i t} \\
\stackrel{N o}{\rightarrow} B C_{i t}\end{array}$ & $B C_{i t} \stackrel{* *}{\rightarrow} r g_{i t}$ & $B C_{i t} \stackrel{N o}{\rightarrow} r t_{i t}$ & $B C_{i t} \stackrel{* *}{\rightarrow}$ drate $_{i t}$ & $B C_{i t} \stackrel{* * *}{\rightarrow} r g d p_{i t}$ & $B C_{i t} \stackrel{N o}{\rightarrow} \pi_{i t}$ \\
\hline $\begin{array}{l}r t_{i t} \\
\stackrel{N o}{\rightarrow} B C_{i t}\end{array}$ & $r t_{i t} \stackrel{* * *}{\rightarrow} r g_{i t}$ & $r g_{i t} \stackrel{N o}{\rightarrow} r t_{i t}$ & $\mathrm{rg}_{i t} \stackrel{\text { No }}{\rightarrow}$ drate $_{i t}$ & $r g_{i t} \stackrel{N o}{\rightarrow} r g d p_{i t}$ & $r g_{i t} \stackrel{N o}{\rightarrow} \pi_{i t}$ \\
\hline $\begin{array}{l}\underset{* * a t e_{i t}}{\text { Ir* }_{i t}} B C_{i t} \\
\end{array}$ & $\begin{array}{l}\text { drate } \\
\text { No } \\
\stackrel{\rightarrow}{\rightarrow} g_{i t}\end{array}$ & $\begin{array}{l}\text { drate }_{i t} \\
\stackrel{\text { *** }}{\rightarrow} r t_{i t} \\
\end{array}$ & $r t_{i t} \stackrel{\text { No }}{\rightarrow}$ drate $_{i t}$ & $r t_{i t} \stackrel{N o}{\rightarrow} r g d p_{i t}$ & $r t_{i t} \stackrel{N o}{\rightarrow} \pi_{i t}$ \\
\hline $\begin{array}{l}r g d p_{i t} \\
\stackrel{* * *}{\rightarrow} B C_{i t}\end{array}$ & $\begin{array}{l}r g d p_{i t} \\
\text { No } r_{g_{i t}} \\
\end{array}$ & $\begin{array}{l}r g d p_{i t} \\
\stackrel{* * *}{\rightarrow} r t_{i t}\end{array}$ & $\begin{array}{l}\operatorname{rgdit}_{\text {*t* }} \\
\stackrel{\text { drate }}{\rightarrow}\end{array}$ & $\begin{array}{l}\text { drate } \\
\stackrel{* * *}{\rightarrow} r g d p_{i t}\end{array}$ & $\begin{array}{l}\text { drate } \\
\text { No } \\
\rightarrow \pi_{i t} \\
\end{array}$ \\
\hline $\begin{array}{l}\pi_{i t} \\
\stackrel{* * *}{\rightarrow} B C_{i t}\end{array}$ & $\pi_{i t} \stackrel{* * *}{\rightarrow} r g_{i t}$ & $\pi_{i t} \stackrel{* * *}{\rightarrow} r t_{i t}$ & $\pi_{i t} \stackrel{* * *}{\rightarrow}$ drate $_{i t}$ & $\pi_{i t} \stackrel{* * *}{\rightarrow} r g d p_{i t}$ & $\begin{array}{l}r g d p_{i t} \\
\stackrel{* * *}{\rightarrow} \pi_{i t} \\
\end{array}$ \\
\hline
\end{tabular}

Notes: The table reports the results of the Granger causality tests, based on equations (1)-(3). The number of lags of instrument variables is set to 5 and the number of lag order of panel VAR, $q$, is 3 , determined as specified above. The direction of the arrow indicates the direction of Granger causality (the first variable causing the second), while the significance level of the rejection of the 
null hypothesis of no Granger causality is indicated by the arrow: No denotes that the null hypothesis (of no Granger causality) cannot be rejected, while */**/*** denote that the hypothesis of no Granger causality can be rejected at the 10\%, 5\%, and 1\% significance level, respectively.

Table 4 conveys the results of Granger causality tests for consumer confidence $\left(C C_{i t}\right)$ for both subperiods, and we focus only on the relationship between fiscal/monetary policy variables and confidence. We find that the growth in government revenues Granger caused consumer confidence in the first subperiod, but not in the second, which is the reverse from what we established for business confidence. The growth of government expenditure Granger caused consumer confidence in the second period, but not in the first. Changes in the ECB's shadow Granger caused business confidence in both subperiods, and reverse, thus indicating a tight, reverse Granger-causal relationship between the variables.

Table 4: Granger causality between fiscal/monetary policy and consumer confidence in subperiods

\begin{tabular}{|l|c|c|}
\hline Subperiod & $\begin{array}{c}\text { Fiscal/monetary policy } \\
\text { variables Granger causing } \\
C C_{i t}\end{array}$ & $\begin{array}{c}C C_{i t} \text { Granger causing } \\
\text { fiscal/monetary variables }\end{array}$ \\
\hline 1999q1-2008q3 & $r g_{i t} \stackrel{\text { No }}{\rightarrow} C C_{i t}$ & $C C_{i t} \stackrel{* *}{\rightarrow} r g_{i t}$ \\
\cline { 2 - 3 } & $r t_{i t} \stackrel{* * *}{\rightarrow} C C_{i t}$ & $C C_{i t} \stackrel{N o}{\rightarrow} r t_{i t}$ \\
\cline { 2 - 3 } & $d r a t e_{i t} \stackrel{*}{\rightarrow} C C_{i t}$ & $C C_{i t} \stackrel{* * *}{\rightarrow} d r a t e_{i t}$ \\
\hline 2008q4-2019q3 & $r g_{i t} \stackrel{* * *}{\rightarrow} C C_{i t}$ & $C C_{i t} \stackrel{\text { No }}{\rightarrow} r g_{i t}$ \\
\cline { 2 - 3 } & $r t_{i t} \stackrel{N o}{\rightarrow} C C_{i t}$ & $C C_{i t} \stackrel{N o}{\rightarrow} r t_{i t}$ \\
\cline { 2 - 3 } & $d r a t e_{i t} \stackrel{* * *}{\rightarrow} C C_{i t}$ & $C C_{i t} \stackrel{* * *}{\rightarrow} d r a t e_{i t}$ \\
\hline
\end{tabular}

Notes: The table reports the results of the Granger causality tests, based on equations (1)-(3). The number of lags of instrument variables is set to 4 and the number of lag order of panel VAR, $q$, is 2 for the period 1999q1-2008q3, and 5 and 2, respectively, for the period 2008q4-2019q3. All other notes from Tables 2 and 3 apply.

Our results regarding the relationship between fiscal policy and consumer/business confidence are at odds with Bachmann and Sims (2012), who argue that US government spending has no effect on consumer confidence, but generally corroborate the results of Konstantinou and Tagkalakis (2011), Alesina et al. (2015), and Beetsma et al. (2015), who show that fiscal policy has a role in the formation of the business and consumer confidence. In line with these studies, we establish that the two fiscal policy instruments (expenditure policy and revenue policy) may affect consumer confidence differently than business confidence, but also the relationship between fiscal policy instruments and confidence is likely to change over time (or business cycle phase ${ }^{8}$ ). 8 The effect of fiscal policies on the economy during different phases of the business cycle is
analyzed, e.g., by Auerbach and Gorodnichenko (2012). 
As for the monetary policy-confidence of economic agents interaction, our results match those from Debes et al. (2014), Claus and Nguyen (2019), Lewis et al. (2019), and Kirchner (2020), who document that monetary policy affects consumer and business confidence. We supplement this literature with a finding that confidence also affects monetary policy. The results also imply that that the Granger causality between the confidence of economic agents and the stance of monetary policy (measured by the shadow rate) is stronger than between the former and the fiscal policy instruments.

As part of sensitivity analysis, we checked whether the fiscal policy-confidence of economic agents relationship is sensitive to the lag order of the panel VAR model. Namely, theoretically, the responses of monetary and fiscal policy to new relevant information may differ in respect of an implementation lag; for example, monetary policy can instantly respond to a major drop in consumer or business confidence and this can be instantly reflected in the policy rate, while it can take considerably more time for the government to address and implement a response to new information due to budgetary procedures. To address this potential issue, the sensitivity analysis is based on model equation (1) with 4 lags. The result of the exercise focused only on the relationship between fiscal policy variables and business and consumer confidence, is shown in Table 5 .

Table 5: Granger causality between fiscal policy and confidence of economic agents: comparison between subperiods

\begin{tabular}{|c|c|c|c|c|c|}
\hline Subperiod & $\begin{array}{c}\text { Lag } \\
\text { order of } \\
\text { panel } \\
\text { VAR } \\
\text { model } \\
\text { equation } \\
\text { (1) }\end{array}$ & $\begin{array}{c}\text { Fiscal policy } \\
\text { variables } \\
\text { Granger } \\
\text { causing } B C_{i t}\end{array}$ & $\begin{array}{c}B C_{i t} \\
\text { Granger } \\
\text { causing } \\
\text { fiscal } \\
\text { variables }\end{array}$ & $\begin{array}{c}\text { Fiscal policy } \\
\text { variables } \\
\text { Granger } \\
\text { causing } C C_{i t}\end{array}$ & $\begin{array}{c}C C_{i t} \text { Granger } \\
\text { causing } \\
\text { fiscal } \\
\text { variables }\end{array}$ \\
\hline \multirow[t]{2}{*}{$\begin{array}{l}1999 q 1- \\
2008 q 3\end{array}$} & \multirow[t]{2}{*}{$q=4$} & $\begin{array}{l}r g_{i t} \\
\stackrel{N o}{\rightarrow} B C_{i t}\end{array}$ & 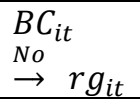 & $\begin{array}{l}r g_{i t} \\
\stackrel{N o}{\rightarrow} C C_{i t}\end{array}$ & $\begin{array}{l}C C_{i t} \\
\text { No } \\
\rightarrow r g_{i t}\end{array}$ \\
\hline & & $\begin{array}{l}r t_{i t} \\
\text { No } \\
\rightarrow B C_{i t}\end{array}$ & $\begin{array}{l}B C_{i t} \\
\stackrel{* * *}{\rightarrow} r t_{i t}\end{array}$ & $r t_{i t} \stackrel{\text { No }}{\rightarrow} C C_{i t}$ & $\begin{array}{l}C C_{i t} \\
\text { No } \\
\rightarrow r t_{i t}\end{array}$ \\
\hline \multirow[t]{2}{*}{$\begin{array}{l}2008 q 4- \\
2019 q 3\end{array}$} & \multirow[t]{2}{*}{$q=4$} & $\begin{array}{l}r g_{i t} \\
\stackrel{N o}{\rightarrow} B C_{i t}\end{array}$ & $\begin{array}{l}B C_{i t} \\
\stackrel{N o}{\rightarrow} r g_{i t}\end{array}$ & $\begin{array}{l}r g_{i t} \\
\stackrel{* *}{\rightarrow} C C_{i t}\end{array}$ & $\begin{array}{l}C C_{i t} \\
\stackrel{* * *}{\rightarrow} r g_{i t}\end{array}$ \\
\hline & & $\begin{array}{l}r t_{i t} \\
\text { No } \\
\stackrel{B}{\rightarrow} B C_{i t}\end{array}$ & $\begin{array}{l}B C_{i t} \\
\stackrel{N o}{\rightarrow} r t_{i t}\end{array}$ & $r t_{i t} \stackrel{\text { No }}{\rightarrow} C C_{i t}$ & $\begin{array}{l}C C_{i t} \\
\text { No } \\
\rightarrow r t_{i t}\end{array}$ \\
\hline
\end{tabular}

Notes: The table reports the results of the Granger causality tests, based on equations (1)-(3). The number of lags of instrument variables is set to 4 or 5 , contingent on the period, and the number of lags is set to 4 and 5. All other notes from Tables 2 and 3 apply.

Table 5 show that the results on the Granger causality interdependence between fiscal policy and business and consumer confidence are not critically dependent on longer lags. This result may suggest that fiscal authority does not pay so much attention to changes in the confidence of economic agents in its policy design as does the monetary authority. It also may suggest, that because of the longer implementation lags of the fiscal policy (and 
thus not being so "well equipped" to counter swings in the confidence of economic agents as the monetary policy) changes in fiscal policy generally do not influence the confidence of economic agents so significantly as monetary policy.

The findings of the paper have important policy implications. Following the literature that examines how confidence affects economic activity (e.g., Matsusaka and Sbordone, 1995; Chauvet and Guo, 2003; Leduc and Sill, 2013), the presented results imply that economic policy can indirectly affect economic activity by affecting the confidence of economic agents. Confidence is an important factor in business cycle dynamics and thus should be monitored and evaluated in the design of the monetary and fiscal policy. Indeed, the results imply that the confidence of economic agents is likely closely monitored by the monetary authority in the euro area and thus influences its monetary policy decisions.

\section{Conclusion}

On a sample of euro area countries and by Granger causality analysis, this paper provides evidence that business and consumer confidence relationship, supplementing the existing literature with evidence for the euro area. We contribute to the literature by investigating the potential causality feedback between economic policy (fiscal and monetary) and both indicators of confidence. The results show the feedback (reverse causality) between both indicators of confidence and changes in the monetary policy rate, whereas this could not be established for the fiscal policy instruments (government expenditure and revenues). We observe some differences in dependence between fiscal policy and confidence in the periods before and after the start of the Great Recession, while the feedback relationship between monetary policy and confidence remains strong throughout. The results of the study bear important policy implications: Confidence is an independent generator of economic activity. As such, it must be monitored and evaluated not just in the design of monetary policy but also in the design of the fiscal policy. Due to differences in the implementation lags of fiscal and monetary policy, the monetary policy may be better equipped to respond to changes in the confidence of economic agents, which is reflected in the finding of a stronger (reverse) Granger causality between monetary policy than fiscal policy and the confidence of economic agents.

Disclosure statement: No potential conflict of interest was reported by the author.

\section{References}

ABRIGO, M. R. M., LOVE, I. (2016), Estimation of panel vector autoregression in Stata, The Stata Journal, Vol. 16, No. 3, pp. 778-804. DOI: $10.1177 / 1536867 X 1601600314$

ALESINA, A., FAVERO, C., GIAVAZZI, F. (2015), The output effect of fiscal consolidation plans, Journal of International Economics, Vol. 96, No. S1, pp. S19-S42. DOI: $10.1016 /$ j.jinteco.2014.11.003

ANDREWS, D.W.K., LU, B. (2001), Consistent model and moment selection procedures for GMM estimation with application to dynamic panel data models, Journal of Econometrics Vol. 101, No. 1, pp. 123-164. DOI: 10.1016/S0304-4076(00)00077-4 
ARELLANO, M., BOVER, O. (1995), Another look at the instrumental variable estimation of error-components models, Journal of Econometrics, Vol. 68, No. 1, pp. 2951. DOI: 10.1016/0304-4076(94)01642-D

AUERBACH, A.J., GORODNICHENKO, Y. (2012), Measuring the Output Response to Fiscal Policy, American Economic Journal: Economic Policy, Vol. 4, No. 2, pp. 1-27.

BACHMANN, R., SIMS, E.R. (2012), Confidence and the Transmission of Policy Shocks, Journal of Monetary Economics, Vol. 59, No. 3, pp. 235-249. DOI: 10.1016/j.jmoneco.2012.02.005

BARSKY, R.B., SIMS, E.R. (2012), Information, Animal Spirits, and the Meaning of Innovations in Consumer Confidence, American Economic Review, Vol. 102, No. 4, pp. 1343-1377. DOI: $10.1257 /$ aer.102.4.1343

BEAUDRY, P., PORTIER, F. (2014), News-Driven Business Cycles: Insights and Challenges, Journal of Economic Literature, Vol. 52, No. 4, pp. 993-1074. DOI: 10.1257/jel.52.4.993

BEETSMA, R., CIMADOMO, J., FORTUNA, O., GIULIODORI, M. (2015), The confidence effects of fiscal consolidations, Economic Policy, Vol. 30, No. 83, pp. 439489. DOI: $10.1093 /$ epolic/eiv007

BOFINGER, P., DEBES, S., GAREIS, J., MAYER, E. (2013), Monetary policy transmission in a model with animal spirits and house price booms and busts, Journal of Economic Dynamics \& Control, Vol. 37, No. 12, pp. 2862-2881. DOI: 10.1016/j.jedc.2013.08.002

BOND, S. (2002), Dynamic panel data models: A guide to micro data methods and practice, Working Paper CWP 09/02, Cemmap, Institute for Fiscal Studies, Department of Economics, UCL, London, 3 April.

CANOVA, F. and CICCARELLI, M. (2013), Panel vector autoregressive models, a survey, Working Paper Series No. 1507, European Central Bank, Frankfurt, January 2013.

CHAUVET M. and GUO, J-T. (2003), Sunspots, animal spirits, and economic fluctuations, Macroeconomic Dynamics, Vol. 7, No. 1, pp. 140-169. DOI: 10.1017/S1365100502010337

CHOI, I. (2001), Unit root tests for panel data, Journal of International Money and Finance, Vol. 20, No. 2, pp. 249-272. DOI: 10.1016/S0261-5606(00)00048-6

CLAUS, E. and NGUYEN, V.H. (2019), Monetary policy shocks from the consumer perspective, Journal of Monetary Economics, first online: DOI: 10.1016/j.jmoneco.2019.03.012

DEBES, S., GAREIS, J., MAYER, E. and RÜTH, S. (2014), Towards a consumer sentiment channel of monetary policy. W.E.P. - Würzburg Economic Papers 91, University of Würzburg, Chair for Monetary Policy and International Economics, Würzburg, October 2014.

DE GRAUWE, P. (2011), Animal spirits and monetary policy, Economic Theory, Vol. 47, No. 2, pp. 423-457. DOI: 10.1007/s00199-010-0543-0 
EICHLER, M. (2013), Causal inference with multiple time series: principles and problems, Philosophical Transactions of the Royal Society A, 371(1997). DOI: $\underline{10.1098 / \text { rsta.2011.0613 }}$

EUROPEAN COMMISSION. (2019), The Joint Harmonised EU Programme of Business and Consumer Surveys User Guide (updated January 2019), European Commission Directorate-General for Economic and Financial Affairs, Bruxelles, available at: https://ec.europa.eu/info/sites/info/files/bcs_user_guide_en_0.pdf.

EUROSTAT. (2020a), GDP and main components (output, expenditure and income) [namq_10_gdp], available

at: https://appsso.eurostat.ec.europa.eu/nui/show.do?dataset=namq_10_gdp\&lang=en.

EUROSTAT. (2020b), Quarterly non-financial accounts for general government [gov_10q_ggnfa], available at: https://appsso.eurostat.ec.europa.eu/nui/show.do?dataset=gov_10q_ggnfa\&lang=en.

EUROSTAT. $(2020 \mathrm{c}), \operatorname{HICP}(2015=100)$ - monthly data (index) [prc_hicp_midx], available at: https://appsso.eurostat.ec.europa.eu/nui/show.do?dataset=prc_hicp_midx\&lang=en.

EUROSTAT. (2020d), Sentiment indicators - monthly data, available at: http://appsso.eurostat.ec.europa.eu/nui/show.do?dataset=ei_bssi_m_r2\&lang=en.

GREENE, W.H. (2002), Econometric Analysis, Fifth Edition, Prentice Hall, Upper Saddle River, New Jersey.

GRUNDOWSKA, S. (2015), JDemetra+ Reference Manual Version 2.1, Narodowy Bank Polski, Department of Statistics, Warszawa, Available at: https://ec.europa.eu/eurostat/cros/system/files/jdemetra_user_guide.pdf.

GUIMARES, B., MACHADO C. and RIBEIRO M. (2016), A Model of the Confidence Channel of Fiscal Policy, Money, Credit and Banking, Vol., 48, No. 7, pp. 1363-1395. DOI: $\underline{10.1111 / j m c b .12336}$

HAMILTON, J.D. (1994), Time Series Analysis, Princeton University Press, Princeton, New Jersey.

HANSEN, L. P. (1982), Large sample properties of generalized method of moments estimators, Econometrica, Vol. 50, No. 3, pp. 1029-1054. DOI: $10.2307 / 1912775$

HSIAO, C. (1982), Autoregressive modeling and causal ordering of econometric variables, Journal of economic Dynamics and Control, Vol. 4, No. 1, pp. 243-259. DOI: $\underline{10.1016 / 0165-1889(82) 90015-X}$

HSIAO, C. (1986), Analysis of panel data, Cambridge University Press, Cambridge.

KIRCHNER, S. (2020), The Effect of Changes in Monetary Policy on Consumer and Business Confidence, The Australian Economic Review, Vol. 53, No. 1, pp. 118-125. DOI: $10.1111 / 1467-8462.12365$

KONSTANTINOU, P., TAGKALAKIS, A. (2011), Boosting confidence: Is there a role for fiscal policy?, Economic Modelling, Vol. 28, No.4, pp. 1629-1641. DOI: 10.1016/j.econmod.2011.02.019 
KRIPPNER, L. (2015), Zero Lower Bound Term Structure Modeling, A Practitioner's Guide, Palgrave Macmillan US, New York, NY.

LEDUC, S., SILL K. (2013), Expectations and Economic Fluctuations: An Analysis Using Survey Data, The Review of Economics and Statistics, Vol. 95, No. 4, pp. 13521367. DOI: 10.1162/REST_a_00374

LEWIS, D.J., MAKRIDIS C., MERTENS K. (2019), Do Monetary Policy Announcements Shift Household Expectations?, Federal Reserve Bank of New York Staff Reports No. 897, New York: Federal Reserve Bank of New York, September 2019.

MATSUSAKA, J.G., SBORDONE, A.M. (1995), Consumer Confidence and Economic Fluctuations, Economic Inquiry, Vol. 33, No. 2, pp. 296-318. DOI: 10.1111/j.14657295.1995.tb01864.X

MERTENS, K., RAVN M.O. (2014), Fiscal Policy in an Expectations Driven Liquidity Trap, Review of Economic Studies, Vol. 81, No. 4, pp. 1637-1667. DOI: 10.1093/restud/rdu016

MOLTENI, F., PAPPA E. (2017), The Combination of Monetary and Fiscal Policy Shocks: A TVP-FAVAR Approach, EUI Working Papers MWP 2017/13 Max Weber Programme, European University Institute, Badia Fiesolana.

NAKATA, T. and SCHMIDT S. (2019), "Expectations-driven liquidity traps: implications for monetary and fiscal policy", Working Paper Series No. 2304, European Central Bank, Frankfurt, August 2019.

RESERVE BANK OF NEW ZEALAND. (2020), Comparison of international monetary policy measures, Available at: https://www.rbnz.govt.nz/research-andpublications/research-programme/additional-research/measures-of-the-stance-of-unitedstates-monetary-policy/comparison-of-international-monetary-policy-measures.

ROSSI, B., ZUBAIRY S. (2011), What is the Importance of Monetary and Fiscal Shocks in Explaining U.S. Macroeconomic Fluctuations?, Journal of Money, Credit and Banking, Vol. 43, No. 6, pp. 1247-1270. DOI: 10.1111/j.1538-4616.2011.00424.X

SCHMIDT, S. (2016), Lack of confidence, the zero lower bound, and the virtue of fiscal rules, Journal of Economic Dynamics and Control, Vol. 70, pp. 36-53. DOI: 10.1016/j.jedc.2016.06.005

SONG, X., TAAMOUTI, A. (2019), A Better Understanding of Granger Causality Analysis: A Big Data Environment, Oxford Bulletin of Economics and Statistics, Vol. 81, No. 4, pp. 911-936. DOI: $10.1111 /$ obes.12288 